\title{
Undersökning av omfattande brott på det ekonomiska livets område
}

\author{
Av kriminalinspektören, jur. kand. KYÖSTI JOUSIMAA.
}

Vår tid håller på att skapa en till synes ny art av brott, vars $\mathrm{i}$ rubriken upptagna namn i allmänhet förkortas med beteckningen ekonomiskt brott, vilken beteckning jag i fortsättningen kommer att använda. Jag använde ovan uttrycket ,till synes“, emedan människorna har en benägenhet att glömma gångna brytningstider och därvid erhållna lärdomar, såsom uttrycket ,,den gamla goda tiden" träffande utvisar. Statistiken utvisar, att antalet brott, bland dem även de om vilka här är fråga, ökar; orsaken ligger enligt vissas uppfattning i kristiden och försämringen av de allmänna ekonomiska konjunkturerna, andra lägger återigen skulden på den alltför höga levnadsstandarden. Enligt en uppfattning beror i synnerhet ökningen av de ekonomiska brotten på stats- och samhällsdirigeringen, som framkallar oppositionslust och bereder åtskilliga tillfällen till oärlighet, andra framför återigen som motsatt orsak den alltför stora personliga friheten. Från historien minns vi, att till företeelserna i samband med det gamla romerska kejsardömets sönderfall hörde all slags oärlighet och strävan efter egen vinning. Liknande kännetecken torde även ha föregått det forna Egyptens ävensom andra tidigare stormakters undergång. Medeltidens slut förmörkades synbarligen av en liknande situation och de franska och ryska revolutionerna torde åtminstone $\mathrm{i}$ viss mån ha fått sin drivkraft av dylika företeelser. Kanhända nuvarande mellanstadium på vägen mot atomåldern — räknat från tiden efter första världskrigets slut — å sin sida har försvagat människornas moraliska motståndskraft i deras väntan på något nytt. Det är betecknande, att ingen enskild stat eller enskilt folk har ,privilegium“ på ifrågavarande slag av brott, utan de begås såväl i väst som öst, ehuru uppgifterna från andra länder naturligtvis är rätt knapphändiga.

\section{Begreppet ekonomiskt brott.}

Man kan tänka sig att all brottslighet har ekonomisk bakgrund eller således att motiven antingen är att skaffa sig själv eller någon annan nytta eller att åsamka annan ekonomisk förlust. Detta innebär dock icke att vilket brott som helst samtidigt vore ett ekonomiskt brott, utan även det sistnämnda bör anses ha bestämda kännetecken, vilka inom doktrinen dock ännu inte i högre grad preciserats. Det torde heller inte vara nödvändigt att utforma någon standarddefinition. Till följd av sakens mångsidighet är det ekonomiska brottets juridiska definition också rätt 
svår att fastlå och skulle en noggrannare undersökning härvidlag fordra ett ingående studium av de fall som inträffat i praktiken. Oberoende av att ekonomiska aspekter föreligger vid så gott som alla brott, har de ofta helt och hållet lämnats utan avseende i själva brottsdefinitionen, då gärningen som sådan riktar sig mot något viktigare intresse. Sålunda är mord mord, trots att gärningsmannens avsikt varit att komma i besittning av ett stort arv eller någon annan ekonomisk fördel och likaså är landsförräderi landsförräderi oberoende av eventuella ekonomiska motiv.

Vidare kan man konstatera, att begreppet egendomsbrott ingalunda är identiskt med begreppet ekonomiskt brott, ehuru de sistnämnda med hänsyn till statistisk och annan uppdelning företrädesvis placerats bland egendomsbrotten. Vanlig eller grov stöld kan inte anses utgöra ett ekonomiskt brott utan att vissa speciella drag föreligger; likaså kan man anse att även vissa andra typiska egendomsbrott — närmast försnillning och bedrägeri - stannar utanför detta begrepp.

För det ekonomiska brottet har man isynnerhet i lekmannakretsar sökt finna vissa delvis icke-juridiska kännetecken, beträffande vilka det för klargörande av begreppen kanhända är nödvändigt at här i korthet redogöra innan den egentliga huvudsaken behandlas. Beteckningen ekonomiskt brott uttrycker redan som sådan det väsentliga; gärningen står således i samband med det ekonomiska livet och därtill anslutna företeelser. Begreppet ekonomiskt bör synbarligen i förhållande till begreppet egendom dels ges en mera begränsad dels en mera vidsträckt betydelse. Ibland har man t. o. m. velat gå så långt att man i detta sammanhang beaktat endast den s. k. offentliga ekonomiska sektorn, men riktigare bör anses, att även privaträttsliga juridiska personers, närmast bolags och med dem jämförliga övriga samfunds samt under vissa förutsättningar även helt privat ekonomi, inbegripes. Som villkor bör dock uppställas, att verkningarna $v$ den skada som förorsakats genom det ekonomiska brottet och som motsvaras av den nytta gärningsmannen erhållit eller åsyftat, icke enbart träffar det primära objektet utan indirekt berör områden utanför detsamma. överensstämmande med denna tolkning utgör t. ex. en verksamhet varigenom en privatägd industriinrättning genom skilda brott försätts ur funktion och varvid den av stängningen uppkomna skadan förutom mot ägaren även riktar sig mot alla anställda och genom dem och deras familjer indirekt mot hela samhället, ett ekonomiskt brott.

Det ekonomiska brottet får dock icke enbart bestå i åstadkommande av skadegörelse eller verksamhet som syftar härtill, utan det huvudsakliga motivet bör vara att bibringa gärningsmannen eller andra nytta varvid nyttan bör stå i direkt samband med själva den brottsliga verksamheten. Enbart ett sabotagemässigt 
förstörande av en konkurrerande fabrik med avsikt att öppna marknaden för egna produkter är i detta avseende ej tillfyllest.

Såväl den uppnådda eller åsyftade nyttan som den uppkomna skadan bör vara avsevärda; de bör ha verklig betydelse. Härigenom uteslutas de till den ,normala brottsligheten“ hörande egendomsbrotten, vid vilka den uppnådda nyttan nominellt nog kan stiga till avsevärda belopp, men som ur helhetssynpunkt betraktat ej har större betydelse.

Som ett karakteristiskt drag för de ekonomiska brotten har man velat anse den omständigheten, att den skyldige i förhållande till objektet borde inneha någonslags förtroendeställning, kassör, ordförande, verkställande direktör, tjänsteman med beslutanderätt, kommunal förtroendeman o. s. v., men av de i praktiken inträffade fallen kan man sluta sig till at denna tolkning är alltför snäv. Även en utomstående person kan med full framgång inleda en dylik verksamhet såsom de stora växel-, checkoch bankbedrägerierna samt de olika slagen av brott mot valutaoch licensbestämmelserna utvisar. Det är naturligtvis en annan sak, att förutsättningen för att en dylik gärning skall lyckas är att vårdslöshet eller felaktigt förfarande inträffat $i$ den omgivning där brottet begåtts. Dessa omständigheter behöver dock ej stå i något delaktighetsförhållande till själva brottet.

Som ett negativt drag kan ytterligare nämnas, att de ekonomiska brotten i offentligheten lätt får politisk färg, om den misstänkte är en offentlig förtroendeman eller en person, vars politiska åskådning är allmänt känd. De politiska motståndarna strävar härvid till att framhålla de av en person eventuellt begångna förseelserna såsom kännetecknande för metoderna inom vederbörandes politiska parti, och inom de egna partikretsarna förklarar man återigen att fråga är om en politisk förföljelse, trots att saken ej skulle ha någon politisk anknytning. Det är naturligtvis svårt att påstå, att politik ej skulle vara inblandad i vissa fall, men denna omständighet kan dock icke anses vara kännetecknande för någon allmän brottstyp, för brott har ju begåtts t. o. m. med religiösa motiv.

Ifrågavarande grupp av brott förses ofta med epitetet ,svårutredda", men ej heller detta kan anses utgöra något kännetecken; alla som i praktiken deltagit i kriminalundersökning vet, att även bland de enklaste grupper av brott kan enstaka fall förekomma, som är synnerligen svåra att utreda. Det ekonomiska brottet består sällan av en gärning eller ens av en räcka liknande gärningar; ofta är fråga om en grupp av de mest olikartade, stundom i kriminellt avseende rätt obetydliga gärningar, varvid föremål för domstols prövning blir en serie bestående av nämnda gärningar och vari bedrägerier, försnillningar, förfalskningar, oredlighet, utpressningar, stölder, tjänstebrott av olika slag o.s. v. 
kan ingå. Det är ej heller nödvändigt att samma person utfört alla gärningar; var och en blir dömd efter sin egen andel, men karakteristiskt för helhetsbegreppet är, att gärningarna tillsammans utformar det ekonomiska brottet, naturligtvis under förutsättning att gärningarna står i av strafflagen förutsatt förhållande till varandra.

Om jag på basen av förenämnda omständigheter skulle vilja definiera begreppet ekonomiskt brott, bleve resultatet följande:

„Med det ekonomiska brottet förstås en verksamhet, som uppkommit av en eller flere till samma eller skilda grupper av brott hörande gärningar och som bör betraktas som en helhet och vari avsikten är att bibringa gärningsmannen eller annan betydande ekonomisk fördel och vars verkningar sträcker sig utöver det primära objektets krets“.

Denna definition är givetvis lika obestämd som många andra definitioner, men svaren på de juridiska frågorna erhålles ju i regel genom tolkning. Såsom redan i förbigående konstaterats utgöres grundelementen i de ekonomiska brotten av de i strafflagen definierade gärningarna, men den under utveckling varande lagstiftningen har skapat åtskilliga andra paragrafer mot vilka man kan bryta och av vilka i första hand bör nämnas reglementerings- och valutabestämmelserna, licensbegränsningarna, skattelagarna och överhuvudtaget alla till den offentliga sektorn anslutna stadganden. Dessutom kan en tjänsteman eller med denne jämförlig person med stöd av de mångtolkade paragraferna rörande tjänstebrott åtalas för snart sagt vilket slag av verksamhet som helst.

\section{Undersökningsmyndigheterna.}

För konsekvensens skull är det skäl att till en början behandla undersökningsmyndigheterna, deras organisation samt under vilka förutsättningar de arbetar. Av naturliga skäl kan jag dröja endast vid förhållandena i Finland.

Enligt bestämmelserna rörande polisverksamheten i Finland ankommer varje slag av undersökningsverksamhet i första hand på polismyndigheterna. Visserligen kan även allmänna åklagaren verkställa undersökningar och likaså kan ett ärende behandlas vid domstol t. o. m. utan att någon som helst förberedande undersökning ägt rum. Bland undersökningsmyndigheterna kan förutom polisen nämnas riksdagens justitieombudsman och statsrådets justitiekansler, vilka förutom sina övriga uppgifter verkställer undersökningar beträffande av tjänsteman och med dem jämförliga personer begångna tjänstefel. Såväl justitieombudsmanna- som justitiekanslersämbetets organisation föranleder dock vissa begränsningar med hänsyn till denna verksamhet. Statens revisionsverk verkställer endast speciella undersökningar, vilka icke kan betraktas som kriminalundersökningar. På senaste 
tid har man i vissa fall vid undersökning av omfattande och politiskt färgade mål tillsatt s. k. sakkunnigkommittéer, vilka i alla avseenden konstaterats kompetenta för dessa uppgifter; endast en representant för den egentliga kriminalundersökningen har saknats. Huvudregeln är dock, att alla brott, således även de ekonomiska, undersökas åtminstone till någon del och i något skede av polismyndigheterna.

Landet har indelats i polisdistrikt, som efter möjlighet till sitt förfogande har en kriminalavdelning eller åtminstone någon i kriminalundersökning bevandrad polisman. I länen har man dessutom tillsatt kriminalpoliscentraler. Vidare har vi centralkriminalpolisen, vars allmänna verksamhetsområde omfattar hela landet och speciella verksamhetsområde Nylands län; på dess specialorgan ankommer i synnerhet undersökningar av omfattande och svårutredda brott. Som undersökare fungerar överkonstaplar och kommissarier och sedan år 1960 tvenne kriminalinspektörer med specialuppgift att undersöka ekonomiska brott. De större städerna får dock med några undantag när sköta alla kriminalundersökningsuppgifter med egna krafter. För huvudstadens vidkommande ter sig detta för en utomstående åtminstone under vissa tider som en oövervinnelig uppgift.

Vilka kompetensfordringar ställes på de personer som utför undersökningsuppgifter och hurudan är deras specialutbildning? För överkonstapels tjänst är folkskoleexamen och polisskolans underbefälsklass tillfyllest, för kommissaries tjänst fordras ytterligare polisskolans befälsklass eller alternativt juridisk examen, som förutsätter studentexamen och universitetsstudier. Av kriminalinspektörerna fordras däremot juriskandidatexamen. I löneavseende motsvarar överkonstapel närmast fältväbel i försvarsmakten, kommissarie löjtnant eller premiärlöjtnant varemot kriminalinspektör uppnår majors nivå och är sålunda den högst avlönade av de personer som utför undersökningsuppgifter. Någon specialutbildning med hänsyn till undersökning av ekonomiska brott har tillsvidare ej kunnat meddelas någon, men trots den bristfälliga utbildningen och de låga kompetensfordringarna bör dock konstateras att man även på detta område uppnått goda resultat, vilket i första hand torde bero pả vederbörande själva, som genom självstudier vid sidan av sin egentliga utbildning har uppnått nuvarande nivå, som egentligen skulle förtjäna bättre verksamhetsförutsättningar.

De personer som utför undersökningsuppgifter utanför polisens krets har i allmänhet juridisk, merkantil eller ekonomisk utbildning eller bör på annat sätt anses speciellt skickliga just på ifrågavarande område. Med hänsyn till egentlig kriminalundersökning saknar vederbörande dock utbildning och erfarenhet. 
De personer som utför undersökningar av ekonomiska brott borde förutom egentliga polismannaegenskaper i första hand ha kriminalpolisutbildning, för det andra borde vederbörande vara jurist, för det tredje bevandrad i ekonomiska frågor, för det fjärde ha kännedom om förvaltningsärenden, för det femte känna till bokföring, för det sjätte vara bankman o. s. v. Han borde förutom de egentliga huvudområdena även känna till deras specialbranscher, förutom finska och svenska behärska åtminstone engelska, tyska och franska, ha ett snabbt intellekt, vara omsorgsfull, uthärdig, representativ, ha god stilistisk förmåga o. s. v. Denna uppräkning kanhända verkar som en parodi, men enligt erfarenhet är den dock överensstämmande med förhållandena i praktiken.

\section{Undersökningen.}

Vid de undersökningar som äger rum utanför polisens krets iakttas i allmänhet ett skriftligt förfarande, m. a. o. undersökaren anskaffar all nödvändig, till buds stående utredning i form av skriftliga utlåtanden, svarsskrifter och även i form av förklaringar av parter och vittnen samt uppgör på basen av det sålunda erhållna materialet ett sammandrag, som ofta har formen av en promemoria eller ett utlåtande. Visserligen verkställes även muntliga förhör varvid protokoll uppgöres, men det är sällsynt att egentligt undersökningsprotokoll avfattas. En omständighet som försvårar arbetet är att den person som utför undersökningen i allmänhet inte innehar polisfullmakter, vilket hindrar användande av tvångs- och säkerhetsåtgärder. En person som fungerar som åklagare har naturligtvis bättre möjligheter i detta avseende, men redan arten av vederbörandes huvudsakliga uppgifter ställer sina egna begränsningar med hänsyn till möjligheterna att utföra undersökningen i form av egentlig kriminalundersökning.

Polismyndigheternas undersökningar av ekonomiska brott följer givetvis alla de huvudlinjer som i allmänhet uppställes för kriminalundersökningar. Undersökningen bör sålunda vara absolut objektiv och noggrann och vid densamma bör såväl negativa som positiva omständigheter beaktas. Undersökningen av ekonomiska brott kännetecknas även för polismyndigheternas vidkommande av skriftlighet, då behandling av skriftliga handlingar upptar en väsentlig del av verksamheten. Genom att bedöma och tolka det skriftliga materialet på rätt sätt lyckas man i många fall bättre med att få sanningen fram än vid vanligt förhör. Det är också alltid säkrast att vederbörande före det han inleder förhören anskaffar det skriftliga material som behövs samt gör sig noga förtrogen därmed. I det skriftliga materialet kan beroende på fallets natur ingå avtalshandlingar, protokoll, korrespondens, bokföring, handlingar utfärdade av myndighe- 
terna, promemorior, förteckningar o. s. v. Först efter genomgång av detta material kan vederbörande börja planera fallets vidare utredning genom förhör och andra åtgärder. I bästa fall har allt erforderligt material redan bifogats polisanmälan, men den som utför undersökningen är rätt ofta tvungen att anslå åtskilligt med tid för dylika förberedande åtgärder. Den omständigheten att vederbörande själv kommer underfund med vad det är fråga om och vid vilka omständigheter han huvudsakligen bör fästa sin uppmärksamhet är åtminstone lika viktig som insamlandet av materialet; däremot är det sällan möjligt att redan i ett tidigare stadium fastslå något bestämt brott. Dessa gärningar rör sig ofta på gränsen mellan brott och laglighet, varvid vederbörande för undvikande av fel som kan medföra tråkiga påföljder för honom själv, till en början bör sträva till att besvara de principiella frågorna. Han borde redan $\mathrm{i}$ ett tidigt stadium komma till samma uppfattning som högsta domstolen efter grundlig genomgång av allt material och eventuellt först efter omröstning stannat för.

Efter de inledande åtgärderna är det nödvändigt att uppgöra en verksamhetsplan, förutan vilken genomförande av den ofta mycket arbetsdryga uppgiften kanhända misslyckas. Under undersökningens förlopp kommer vederbörande dock ofta att märka, att planen i själva verket ej kan efterföljas i alla avseenden, men han får inte låta denna omständighet inverka, då även en bristfällig plan är bättre än att arbeta utan mål. Förutom denna egentliga verksamhetsplan är det skäl att för varje viktigare förhör uppgöra en särskild förteckning och en tidtabell för att försäkra sig om, att alla nödvändiga frågor blir ställda och i rätt ordningsföljd. Då det område på vilket förhöret rör sig ofta är vidsträckt och för vederbörande obekant kan uppgörande av protokoll vid avsaknad av förhandsplanering bli en övermäktig uppgift.

Stundom är det möjligt att använda sig av det vid sedvanlig kriminalundersökning bannlysta förfarandet, enligt vilket den som utför undersökningen på förhand uppgör skriftliga frågor samt låter vederbörande i lugn och ro stifta bekantskap med frågorna och besvara dem skriftligt dock sålunda, att allt gås igenom även vid det formella förhöret, varvid båda parterna har möjlighet att för egen del komplettera saken. Detta påminner i hög grad om den redan tidigare nämnda metoden med avgivande av förklaringar och utlåtanden, som används vid vanligt förvaltningsförfarande, men genom att uppgifterna vid det officiella förhöret bekräftas och kontrolleras kan denna metod användas även vid kriminalundersökningar. Härvid bör man dock förfara med stor försiktighet samt omsorgsfullt pröva vid vilka tillfällen metoden kan användas utan risk. Till systemets nack- 
delar hör bl. a., att den misstänkte i fred och ro hinner utforma sina svar, kan kontakta andra personer, kan försöka påverka vittnena o.s. v. och framförallt avslöjar frågeställningen eventuellt för honom allt vad myndigheterna känner till i saken, varvid man ej längre har möjlighet att vid det egentliga förhöret framställa överraskande frågor. Metoden är dock lämplig att användas i sådana fall där protokollet kommer att innehålla ett avsevärt antal tal, datum, namn och annat sådant, som det kan vara svårt att minnas vid själva förhöret. Rättegångsbalkens stadgande, enligt vilket vittne kan förpliktas att på förhand erinra sig någon omständighet samt studera erforderliga handlingar, kan anses utgöra en grund för en dylik praxis. Användandet av denna metod vid polisförhöret beror dock först och främst på den person med hänsyn till vilken densamma skall tillämpas. Om den som utför undersökningen i minsta mån misstänker, att den avhörde ej kommer att vara ärlig, är det bäst att förkasta hela idéen med skriftliga frågor och inleda normalt förhör, trots att detta kan ta månader i anspråk. En naturlig och i alla avseenden godtagbar åtgärd är däremot att den som anländer till förhöret uppmanas medtaga allt till buds stående material som belyser saken. Härigenom blir förhöret kortare och sakligare, då man beträffande vissa punkter endast behöver hänvisa till de framlagda handlingarna, som på teknisk väg kan kopieras under förhörets gång så att originalen kan återlämnas efter förhöret.

De personer som begår ekonomiska brott är ofta med hänsyn till sin intelligens över medelnivån och är dessutom vanligen fackmän på sina egna områden. Denna omständighet ställer stränga krảv på undersökningsmyndigheterna, som för att kunna behärska situationen redan från början bör få övertaget i förhållande till den misstänkte. Därför bör man före det andra åtgärder vidtages möjligast noggrant göra sig förtrogen med det område, som undersökningar rör sig på. Detta sker naturligtvis bäst på själva brottsplatsen sålunda, att undersökaren studerar utvecklingen av andra liknande fall och noga observerar de olika utvecklingsstadierna, svagheterna i tillvägagångssätten, olika personers uppträdande samt huru dessa förhållit sig till saken. Om den som utför undersökningen ej förberett sig på detta sätt kommer han kanhända att famla i mörker och får som invändningar ta emot nästan vilka slag av uttalanden som helst.

I allmänhet rekommenderas en sådan förhörsmetod, enligt vilken vederbörande till en början får framföra sin berättelse $\mathrm{i}$ en följd, varefter den antecknas i protokollet samtidigt som den person som utför undersökningen framställer kompletterande frågor; denna metod kräver koncentration och gott minne av bägge parterna. Vid omfattande utredningar kan ej ens en ruti- 
nerad förhörare använda denna metod utan vid förhöret måste i första hand iakttas metoden med att ställa frågor. Det torde dock kunna rekommenderas, att berättelsens huvuddrag i form av en fortlöpande skildring intas i protokollet, varefter detaljerna i tur och ordning omsorgsfullt genomgås, Härvid förlänges givetvis berättelsen, men för en utomstående ställer det sig lättare att få reda på detaljerna efter det ett helhetsintryck erhållits.

Vid omfattande ärenden kan förhöret sällan slutföras under ett förhörstillfälle, utan måste ibland fortsättas t. o.m. vid ett tiotal tillfällen. Vid avbrytandet av förhöret bör dock förfaras sålunda, att ingen detalj blir öppen utan protokollet bör efter varje förhörstillfälle kunna avslutas på ett konsekvent sätt. Den som verkställer undersökningen gör bäst $\mathbf{i}$ att glömma bort sådana begrepp som tjänstetid och fridagar och i stället enbart koncentrera sig på att kunna slutföra undersökningen.

Såvida händelseförloppet ej kan klarläggas genom skriftliga handlingar eller vittnesberättelser bör man även med hänsyn till målsägarna iaktta försiktighet. Erfarenheten har nämligen visat att dessa antingen i hopp om ersättning eller för att dölja egna fel strävar till att framställa skadorna större än de i verkligheten är och t. o.m. försöker hitta på obegångna brott för att förbättra sin egen ställning.

Även vid vittnesförhör kan svårigheter uppkomma, då ofta de enda personer som känner till saken är underställda eller står $\mathrm{i}$ annat beroendeförhållande till någondera parten. Vid förhör av ett dylikt vittne är det därför skäl att till en början redogöra för vittnesutsagans innebörd samt erinra om det straffpåföljder som kan riktas mot ett lögnaktigt eller vårdlöst vittne.

Det har även blivit rätt vanligt att man genom analogisk tilllämpning av de till rättegångsbalken år 1948 fogade stadgandena uppmärksamgör vittnet på det straff som följer på osann utsaga vid polisförhör. Vid vittnesförhör har man' för övrigt strävat till att iaktta rättegångsbalkens bestämmelser angående förfarandet vid domstol då ett motsatt förfarande i ett senare skede av processen eventuellt kan leda till oberäkneliga följder och då man numera lutar åt den uppfattningen, att kriminalundersökningen ehuru den äger rum utanför domstol dock utgör ett inledande avsnitt av domstolsförhandlingen. Ett problem som lyckligtvis uppstår rätt sällan, utgöres i ärenden av detta slag av bestämmelsen i rättegångsbalkens 17 kap. 24 §, enligt vilken vittne är berättigat att underlåta att yppa affärs- eller yrkeshemlighet, såvida icke synnerligen vägande skäl föreligger. Då en dylik invändning framställes har den som utför undersökningen ej annan möjlighet än att anteckna nekandet och motiveringen härför $\mathrm{i}$ protokollet och äverlåta frågan om eventuellt förpliktande att avge vittnesmål att i sinom tid avgöras av dom- 
stol. Likaså kan svårigheter uppstå om ett vittne vägrar att ställa skriftliga handlingar till undersökningsmyndigheternas disposition, men spörsmål av detta slag hör redan till processrätten.

Vid förhör av en person som är motsträvig eller har dåligt minne är det ofta säkrast att använda metoden med frågor och svar, varvid dessa ordagrant antecknas i protokollet. Förutom exaktheten har metoden den fördelen, att samma frågor kan ställas till någon annan person varefter svaren jämföras med varandra. I synnerhet bedömandet och värdesättandet av sinsemellan stridande uttalanden underlättas härigenom betydligt.

Likaså kan förhör inledas samtidigt med flere personer, men då bör den som utför undersökningen hela tiden fungera som ordförande. I dessa fall är det bäst att man vid uppgörande av protokollet använder sig av stenograf eller magnetofon, då det är omöjligt att diktera ett tillförlitligt protokoll samtidigt som man skall leda och följa diskussionen.

Vid uppgörande av protokollet bör man vara synnerligen omsorgsfull och undvika alltför förenklad stil, då problemets lösning kan dölja sig i valet av uttryckssätt. Vid dylika brott har protokollen en tendens att bli oproportionerligt långa i förhållande till protokollen över andra brott, men det är också svårt att utelämna något då helhetsintrycket kan bli lidande genom alltför radikala förkortningar.

Vid genomgången av protokollet tillsammans med den förhörde bör man iaktta ännu större omsorgsfullhet än normalt, emedan, såsom tidigare nämts, protokollet kan innehålla åtskilligt med tal, datum, namn och olika slag av förteckningar. Det mest praktiska torde vara att låta vederbörande i lugn och ro läsa igenom protokollet samt med egen handstil och egen penna göra eventuella ändringar. Härigenom är det lätt att bestrida kanhända senare framställda invändningar, emedan handstilen utvisar att vederbörande själv haft tillfälle att kontrollera sin berättelse.

Frågan huruvida man vid komplicerade fall borde avstå från den gamla tillförlitliga metoden med att uppgöra protokollet vid förhörstillfället och i stället övergå till magnetofon har varit föremål för livlig diskussion.

Magnetofonen är ett utomordentligt hjälpmedel t. ex. vid förhör av oförskämda personer, då vetskapen om att allt som sagts bevaras, är ägnad att lugna talaren. Jag skulle dock anse, att ett mekaniskt upptagande av berättelsen åtminstone tillsvidare endast är ett hjälpmedel att användas i speciella fall och att det vedertagna sättet att föra protokollet är den säkraste och mest konsekventa metoden.

Ovan framförda åsikter rörande förhöret utgör givetvis endast 
allmänna riktlinjer, som med framgång kan tillämpas i all kriminalundersökning, men beaktandet av ovannämnda omständigheter är särskilt viktigt i synnerhet vid undersökning av ekonomiska brott. Det är ej möjligt att inom ramen för denna framställning gå in på mera detaljerade frågor, i synnerhet på grund av att varje ärende har sin speciella karaktär, i enlighet med vilken undersökningsmyndigheterna smidigt bör kunna anpassa sin taktik.

Att uppgöra protokollet och att få händelserna antecknade i rätt ordningsföljd kan i samband med undersökningen av ekonomiska brott ofta ta relativt lång tid. Protokollen över omfattande och komplicerade fall bör vara klart och tydligt skrivna samt i tillräckligt hög grad uppdelade i olika avsnitt, varför den som utför undersökningen sålunda vid behov bör kunna avvika från det vedertagna protokollsschemat och uteslutande koncentrera sig på ändamålsenlighetssynpunkter samt sträva till att uppnå ett så enhetligt slutresultat som möjligt. Uppgörande av protokoll är på sätt och vis ,konst“, vid vars utövande man lätt kan gå till överdrifter och risk föreligger för att själva huvudsaken blir åsidosatt om man använder alltför invecklade satskonstruktioner. Enligt vissa personers åsikt borde protokollet ej innehålla något sammandrag och i mindre och okomplicerade fall kan detsamma även med lätthet bortlämnas. Enligt min åsikt är det dock nödvändigt att i mera komplicerade fall uppgöra ett sammandrag, då läsaren härvid lättare kan bilda sig en uppfattning om saken och göra klart för sig, vilka myndigheternas egna iakttagelser är samt vilka åtgärder dessa vidtagit och med hurudane resultat. Det är dock klart, att även sammandraget bör innehålla enbart fakta: det får ej i något sammanhang uttrycka förhörsledarens egna tankar och personliga åsikter. Sammandraget kunde givetvis även ersättas genom att den som utfört undersökningen kallas att avge vittnesmål om sina åtgärder inför rätta, men ett dylikt förfarande skulle leda till många besvärligheter och dröjsmål. Protokollet utgör grunden för åtal och andra åtgärder och om det är väl uppgjort underlättas i ett senare skede domstolens, åklagarens och parternas arbete.

Intagandet av det mestadels mycket omfattande skriftliga materialet i protokollet bereder ofta svårigheter. Man ser of ta protokoll som på grund av i onödan intagna handlingar har svällt ut och var sidoantalet lätt hade kunnat minskas genom att mindre värdefulla handlingar bifogats som bilagor. Om det är nödvändigt att kopiera handlingar är det bäst att använda sig av ljuskopior, fotografier eller liknande metoder, som gör att kopian och originalet blir identiska till det yttre. Om maskinskrivna avskrifter måste tas, vore det bäst att härvid använda samma blanketter som originalen skrivits på. Huvudregeln bör 
dock vara den att originalhandlingarna bifogas till protokollet.

Då man strävar till att avfatta ett så tydligt protokoll som möjligt får man ej underlåta att uppgöra sammandrag, tabeller och förteckningar; något skede i händelseförloppet kan förtydligas genom ritningar och andra bilagor. Det bör även observeras, att ett alltför omfattande enhetligt protokoll ,tröttar ut“ läsaren och den som uppgör protokollet bör vid behov kunna bedöma huruvida icke en uppdelning av undersökningsresultaten på separata mindre protokoll vore på sin plats. Det finns flere grunder enligt vilka uppdelning kan ske, men som en av dessa grunder bör beaktas den omständigheten, att då flere personer står som svaranden för gärningar vilka är att betrakta som skilda brott bör såväl behandlingen av de skilda målen som framförande av besvär kunna äga rum separat utan att de övriga målen inblandas, vilket förutom risken för sammanblandning medför onödiga kostnader vid utlösandet av avskrifter.

För att underlätta det egna arbetet och för att undvika minnesfel uppgör en kompetent person vid undersökningen av komplicerade fall olika slag av kartotek och förteckningar. Det är skäl att även efter det ärendet slutbehandlats förvara dylika hjälpregister tillsammans med övrigt arkiverat material, då registren utgör den väsentliga delen av materialet och då de eventuellt kan vara till nytta vid senare kriminalundersökningar.

Vid undersökningen av ekonomiska brott måste man ofta för att kunna lösa de mångskiftande problem som uppstår ty sig till experters utlåtanden. Förutom sedvanliga kriminallaboratorieundersökningar, såsom jämförelse av handstilar och dokument, bläckundersökningar o.s. v., måste olika slag av uträkningar och värderingar t. o. m. beträffande rent abstrakta frågor anskaffas. Expertutlåtanden rörande tidigare inträffade ekonomiska händelser och dessas innebörd, olika slag av indexserier o. a. dyl. kan även behövas. För att kontrollera någon sak bör arkiv- och statistikstudier bedrivas, gamla tidningsårgångar genomgås och många andra åtgärder vidtagas. Den som utför undersökningen bör alltid ha klart för sig vilka uppgifter han behöver och varför, vidare bör han vid undersökningarna kunna använda sig av uppgifterna. Framförallt bör han sträva till att komma underfund med den verkliga innebörden av ett utlåtande eller en annan uppgift och vid behov bör han ytterligare genom att personligen konsultera expertis försäkra sig om att han verkligen uppfattat svaret rätt; det är naturligtvis även nyttigt att känna till de faktorer, på basen av vilka experten motiverat sin slutledning.

En av de viktigaste grupperna av experter utgöres av revisorerna. Till anmälan om brottet har ofta en revisionsberättelse bifogats, vilket givetvis underlättar undersökningen men som 
ingalunda befriar den som utför undersökningen från att göra åtminstone stickprov. Av revisionsberättelsen framgår dock vanligen endast de punkter beträffande vilka oklarhet synes föreligga samt markbeloppen. Däremot framgår det icke på vilket sätt och varför ifrågavarande fel har uppstått eller vem som är skyldig till detta. Den som utför undersökningen bör på annat sätt sträva till att klargöra dessa väsentliga och avgörande omständigheter, men utan att själv studera bokföringen är detta ej möjligt redan på den grund, att vederbörande bör vid verkställande av förhör på basen av revisionsberättelsen utan besvär finna de aktuella punkterna i bokföringen för att kunna framställa dem i deras ursprungliga form. Såvida vederbörande ej har kännedom om bokföring och des grunder ställs han inför en så gott som oövervinnerlig uppgift då förhör i närvaro av en expert ej alltid leder till önskat resultat; man förlorar härvid lätt greppet om situationen, varvid risk föreligger att hela undersökningen misslyckas. Då revisorer konsulteras borde man hålla sig till verkliga sakkunniga, helst edsvurna revisorer eller revisorer som handlar under tjänstemannaansvar. Polismyndigheternas möjligheter att låta verkställa revision är dock till följd av ekonomiska skäl tämligen begränsade, då verkställande av en flere år omfattande grundlig revision ställer sig tämligen dyrt. Experterna vid statens revisionsverk och finansministeriet intresserar sig i regel endast för de fall, där missbruk av statsmedel eller oklarheter beträffande skatter kan tänkas föreligga. Vid undersökning av ekonomiska brott blir frågan om utländsk handräckning ofta aktuell. Härvid kommer närmast Interpol i fråga, men stundom tas direkt kontakt med polisen $\mathrm{i}$ vederbörande land, ehuru denna kontakt enligt huvudregeln borde ske via centralkriminalpolisen. Lagstiftningen i de olika länderna ställer dock sina egna begränsningar härvidlag, varför den som utför undersökningen ej bör bli förvånad om han får mottaga ett artigt meddelande om att de begärda upplysningarna ej kan lämnas.

Ett svårt problem vid dessa brott utgöres av tvångs- och säkerhetsmedlen, av vilka jag till en början i korthet skall beröra anhållande och häktning. Då undersökningarna kan ta månader i anspråk och då anhållningstiden är begränsad till tre dygn, vilken tid endast på grund av tvingande skäl kan förlängas med fjorton dygn, bör åtgärderna noga övervägas. Det är utan vidare klart, att de vilka gjort sig skyldiga till direkta försnillningar, bedrägerier och förfalskningar bör anhållas och häktas i den mån de allmänna förutsättningarna härför föreligger trots att den som utför undersökningen är tvungen att hänskjuta ärendet till domstol, ehuru undersökningen ofta ej hunnit slutföras, under det att domstolsbehandlingen till föjld av uppskovsbeslut 
förlänges. För arbetsfridens skull verkställer man inte gärna anhållande vid fall som ligger på gränsen till brott. Även domstolen och åklagaren kan lättare behandla ett ärende för vars del undersökningarna slutförts utan de korta uppskov som häktning medför. Den allmänna opinionen förstår visserligen inte detta, utan anser vanligtvis att någon person gynnats utan att dock ha reda på den verkliga orsaken.

Undersökning som sker enligt de allmänna av lagen fastställda riktlinjerna kan visa sig synnerligen svår att genomföra, om den person som utför undersökningen ej har klart för sig vad han bör söka efter och vad som kan vara av betydelse. Husundersökning hör ju i allmänhet till det första stadiet av undersökningsåtgärder, varför antalet handlingar och föremål som undersökes i samband därmed hellre får vara alltför stort än alltför litet, då någon omständighet som icke observerats i ett senare stadium eventuellt kan ha avgörande betydelse. Med hänsyn till kvarstad kommer i synnerhet de i lagen uttryckligen nämnda begränsningarna då och då i fråga, men det torde ej vara nödvändigt att i detta sammanhang redogöra för dessa.

Det är kanhända skäl att även med några ord beröra förhållandet mellan undersökningsmyndigheterna och det offentliga ordet. Det ekonomiska brottet innebär ofta i ett visst avseende samtidigt en skandal, varför det är förståeligt, att pressen noga följer med fallets behandling i de olika instanserna. Den som utför undersökningen har skäl att vara synnerligen försiktig och diplomatisk beträffande information, eftersom han såsom tidigare nämnts sällan ens kan ana sig till slutresultatet. Å andra sidan kan en absolut tystlåtenhet ge upphov till felaktiga nyheter genom att redaktörerna sammanställer upplysningar som de erhållit från skilda källor. Det är svårt att senare korrigera en felaktig uppfattning som redan slagit rot i det allmänna medvetandet.

På grund av de ekonomiska brottens komplicerade karaktär diskuteras ofta frågan om den bästa och snabbaste undersökningsmetoden. Enligt en åsikt borde ett tillräckligt antal personer lösgöras för undersökningarna. Av dessa skulle var och en ha sin uppgift i det att en person skulle bära ansvaret för undersökningen. På detta sätt kan undersökningen givetvis slutföras snabbare, men då vederbörande arbetat efter egna metoder blir resultatet oenhetligt. Säkrast är att ge uppdraget åt en person, som efter egen prövning får utse medhjälpare utan att anförtro dessa uppgifter av avgörande betydelse. Undersökningen av ekonomiska brott kan sällan hänföras till kategorin klassiskt detektivarbete då den som utför undersökningen i många fall knappast ens behöver avlägsna sig från sitt arbetsrum. 


\section{Framtida arrangemang.}

Under senaste tid har man i vårt land utfört flere till denna kategori hörande synnerligen komplicerade utredningar, av vilka jag t. ex. kan nämna det s. k. skogsersättningsmålet, där de flesta av svarandena var jurister, de stora valuta- och välgörenhetsmålen, där undersökningarna rörde sig på samhällets högsta nivå, vissa $\mathrm{i}$ banker och andra samfund begångna försnillningar, växel- och checkbedrägerier samt vissa politiskt färgade mål, vilka av den allmänna opinionen betraktats som skandalartade. Vissa av dessa undersökningar har, såsom tidigare konstaterats, slutförts och hänskjutits till domstol utan att egentlig polisundersökning ägt rum, ehuru man även i detta fall enligt allmänhetens uppfattning borde ha anförtrott undersökningarnas utförande på polismyndigheterna såsom fallet är vid andra brott. Erfarenheterna från dessa fall har icke på nagot sätt sammanställts, men någonting borde göras för att förenhetliga metoderna och för att kunna uppnå så exakta resultat som möjligt, för att få en objektiv undersökning och för att kunna garantera en likvärdig behandling av alla. Enligt min åsikt innehar polismyndigheterna de bästa förutsättningarna att sköta all kriminalundersökning, såvida man bereder ifrågavarande myndigheter möjligheter, medel och skäliga ekonomiska villkor. För dessa uppgifter borde man anställa ett erforderligt antal personer med tillräcklig allmänbildning samt avlöna dessa alltefter uppgifternas svårighetsgrad och art. Juridisk eller ekonomisk slutexamen torde utgöra en lämplig utgångspunkt, men enbart detta är ej tillfyllest, utan ytterligare kräves grundlig praktisk erfarenhet samt även tillräcklig polisutbildning. Den kanhända bästa lösningen vore att öka antalet kriminalinspektörsvakanser vid centralkriminalpolisen och uppdela landet i territoriellt hänseende mellan inspektörerna varvid en av dem skulle fungera som äldste och vara underställd centralkriminalpolisens högsta ledning. På så sätt kunde man åstadkomma tidigare nämnda erforderliga enhetlighet $\mathrm{i}$ verksamheten och dessutom behandla ett avsevärt större antal fall än tidigare.

\section{Diskussionspunkter.}

De ekonomiska brotten utgör sålunda på sätt och vis ett internationellt problem som medför att åtminstone polismyndigheterna i angränsande länder vid undersökningen av dessa brott är tvungna att inleda ett intimt samarbete. Härför vore det kanhända att till en början diskutera huruvida man mellan de nordiska länderna, var's strafflagar och undersökningsmetoder i hög grad påminner om varandra kunde uppnå enhetlighet beträffande såväl brottdefinitionen som beträffande de åtgärder, som föranledes av dessa brott. 
I det egentliga avsnittet av min framställning har jag genom att studera vissa kännetecken, vilka dock icke utformats av doktrinen, utan av praxis och delvis även av det offentliga ordet och som sålunda saknar vetenskaplig giltighet, kommit fram till en slags definition av det ekonomiska brottet. Beträffande nyttan av denna definition kan man givetvis ha olika åsikter. I detta sammanhang har jag konsterat, att alla brott kan tänkas ha ekonomiska motiv utan att de utgör ekonomiska brott i den bemärkelse detta begrepp här givits, och att begreppen ekonomiskt brott och egendomsbrott ingalunda alltid är identiska. Till det ekonomiska brottets väsen hör enligt min åsikt i första hand, att den kriminella verksamheten bör äga rum på det ekonomiska livets område. Vidare bör den genom brottet erhållna nyttan vara avsevärd, och den motsvarande skadan bör å andra sidan åtminstone indirekt utsträcka sig även utanför det egentliga objektets område; däremot får avsikten med brottet ej enbart utgöras av vilja att åsamka annan skada. Det ekonomiska brottet kan bestå av en enda gärning, men oftast är det dock fråga om en serie gärningar, vilka bör betraktas som skilda brott, varvid gärningarna tillsammans utformar en bestämd helhet eller just det ekonomiska brottet.

Undersökningen av ekonomiska brott har åtminstone i vårt land icke anordnats på bästa möjliga sätt, vilket man kan sluta sig till redan därav, att undersökningarnas utförande ej koncentrerats på någon bestämt organ, vilket skulle innebära enhetliga verksamhetsåtgärder. Detta kan man förstå om man å andra sidan beaktar de verkligen begränsade möjligheter som står polismyndigheterna till buds, den anspråkslösa nivån som grund- och specialutbildningen befinner sig på samt de låga lönerna, vilka torde utgöra de största hindret för att få t. ex. personer med juridisk examen att intressera sig närmast för kriminalundersökningsuppgifter, vid vilka inga möjligheter till extra inkomster i samband med tjänsten står att finna och vid vilka uppgifternas art och den oregelbundna arbetstiden hindrar vederbörande från att inneha bitjänster. Undersökningen kunde även i organisatoriskt avseende anordnas på annat sätt för att kunna uppnå bästa möjliga resultat; det vore synnerligen viktigt att undersökningsmyndigheterna på ett effektivare sätt än hittills kunde konsultera experter, närmast revisorer, helst sålunda att dessa i organisatoriskt avseende skulle tillhöra undersökningsmaskineriet, utan att man härvid behövde iaktta de formaliteter i samband med anslag och begäran om handräckning som gör verksamheten osmidig och osäker.

I det egentliga avsnittet av denna framställning har specialutbildningen berörts endast i förbigående, men som diskussionsobjekt kan denna fråga vara mycket givande. Om man i fram- 
tiden kommer därhän, att kriminalinspektörsvakanserna kan besättas av personer med tillräcklig juridisk och ekonomisk utbildning, utgör specialutbildningen givetvis inte något svårt problem, i synnerhet om vederbörande har tillräcklig praktisk erfarenhet. I sistnämnda hänseende räcker det med att koncentrera sig på vissa områden, beträffande vilka tilläggskunskaper kan erhållas genom självstudier, under förutsättning att erforderligt studiematerial står att finna. Såvida utbildningen sker utgående från lägre kompetensfordringar borde densamma enligt min uppfattning anordnas $\mathrm{i}$ form av tillräckligt långa kurser varvid undervisningen skulle omfatta åtminstone följande ämnen: bokföring, bankväsendet och dess olika betalningsformer, skötseln av statens och övriga offentliga samfunds ekonomi $i$ huvuddrag, affärslivets juridik, möjligheterna att konsultera i detta sammanhang aktuell expertis o.s. v. Vederbörande borde även erhålla erforderlig åskådlig undervisning samt vara i tillfälle att följa med händelserna i det praktiska livet.

Av ovanstående torde framgå, att polismyndigheterna enligt min åsikt har de bästa förutsättningarna att verkställa undersökningar även beträffande ekonomiska frågor, under förutsättning att tillräckligt med manskap, materiel och medel står till deras förfogande. Om man dock i vissa fall nödvändigtvis vill utföra undersökningarna på annat sätt borde polismyndigheterna oberoende härav medverka i någon form, då först och främst utförande av undersökningar utan polisfullmakter ställer sig svårt. Vidare underlättar polismyndigheternas erfarenhet redan tack vare den inlärda rutinen undersökningarnas framskridande och framförallt är deras medverkan ägnad att lugna allmänheten, emedan medborgarnas absoluta majoritet förlitar sig på myndigheternas saklighet, objektivitet och framgång, om också de till föjld av vissa i praktiken inträffade händelser kanhända ansetts inkompententa.

I allmänhet anklagas polismyndigheterna för osmidighet och småaktighet, varvid man glömmer att lagarna och till dem anslutna straffbestämmelser ingalunda utformats av polismyndigheterna utan av folkrepresentationen. Kanhända en polisman någon gång själv tycker sig vara tvungen att gå alltför långt för att inte bryta mot de bestämmelser som förpliktar honom själv. Ovan har jag konstaterat att undersökningen av ekonomiska brott följer samma principer som annan kriminalundersökning och att undersökningen bör vara ingående och objektiv. I samband med undersökningar av viss betydelse är polismannen vid fattande av avgörande mellan större och mindre intressen eller skador dock stundom tvungen att avsiktligen bryta mot sina tjänsteplikter. Det skulle verka besynnerligt om den som utreder en miljonförsnillning vore tvungen att bötfalla nyckelvitt- 
net för att vederbörande vid ankomsten till förhörsplatsen gjort sig skyldig till felparkering. För att inte riskera att misslyckas med utredningen torde det vara bättre att i detta fall hellre ta emot klander än att förarga ett vittne som kanhända dessutom varit $\mathrm{i}$ god tro. Min uppfattning är att det mindre intresset $\mathrm{i}$ dylika fall bör vika för det större och om det förstnämnda verkligen kräver åtgärder, bör dessa uppskjutas eller anförtros någon utomstående person.

Det torde vara svårt att från den egentliga undersökningens område avskilja något intressant diskussionsämne, emedan man härvid skulle komma att beröra huvudlinjerna, d. v. s. de omfattande principiella spörsmålen som är gemensamma för hela rättsordningen. Kanhända det dock är skäl att ånyo beröra behandlingen av skriftliga handlingar samt användande av på förhand avfattade berättelser, vilket jag tidigare dels godkänt dels förkastat. Polisundersökningen är ju ett muntligt-protokollariskt förfarande, vid vilket varje inblandad personligen måste avge sin berättelse. Med hänsyn till egentligt skriftligt material torde ingenting misstänkt ligga däri att det som sådant godkännes som bevismaterial och antingen intas i eller bifogas till protokollet, men enligt min uppfattning bör den som utför undersökningen dock alltid efter prövning försäkra sig om materialets tillförlitlighet. I allmänhet anser man ju att en avskrift vars riktighet bevittnats av två personer är tillfyllest, men även i detta avseende har man fått erfara besvikelser i form av förfalskade avskrifter. Jag anser att den som utför undersökningen bör ansvara för urkundens riktighet efter det han mottagit och godkänt densamma med påföljd, att åtgärder kan riktas även mot honom om undersökningarna leder till felaktigt resultat och om han inte i tillräcklig grad försäkrat sig om urkundens äkthed.

Angående för- och nackdelarna med skriftliga vittnesmål har tidigare i huvuddrag redogjorts och om man bokstavligen följde det förfarande som den till rättegångsbalken år 1948 fogade bestämmelsen föreskriver, vore användande av skriftliga vittnesmål med hänsyn till vittnen otillåtet. För min egen del anser jag dock, att mottagande av skriftliga utlåtanden i vissa fall rentav är att rekommendera, under förutsättning att de på vederbörligt sätt bekräftas vid officiellt förhör.

Då undersökningarna av ekonomiska brott till följd av att de personer vilka bör underkastas förhör är bosatta på olika orter och ibland även utomlands ofta utsträcker sig över ett vidsträckt område, måste undersökaren välja mellan handräckning och självständig verksamhet. De lokala polismyndigheterna har svårt att få resetillstånd åtminstone för längre resor och längre tid; detta hinder existerar givetvis inte för personer med större verksamhetsområde, varvid de sistnämnda uteslutande ställs inför 
prövning av ändamålsenlighetssynpunkter. Såsom i annan polisverksamhet håller man även med hänsyn till resor fast vid sparsamhetssynpunkter, varvid den omständigheten att utredningen av ett brott är värdefullare för samhället än en inbesparing av 10.000 mark, ofta blir bortglömd. Enligt min uppfattning borde vederbörande själv på eget ansvar få fatta beslut om eventuella resor åtminstone inom landet. Ett fortsatt resande är inte så angenämt och inte heller är reseersättningarna så stora, att dessa omständigheter skulle vara ägnade att locka någon till att företa onödiga resor. Beträffande ärenden med anknytning till utlandet anser jag även att personlig kontakt är mera givande än formell korrespondens, trotts att även i detta sammanhang sparsamhetssynpunkterna fram till en viss gräns bör beaktas.

Från denna framställning har givetvis flere betydelsesfulla omständigheter utelämnats, men jag hoppas dock att de viktigaste huvuddragen blivit nämnda.

Kyösti Jousimaa. 